\title{
O ANJO DA HISTÓRIA TEM CORPO \\ DE MULHER
}

EL ÁNGEL DE LA HISTORIA TIENE CUERPO DE MUJER

Camila Carvalho*

RESUMO: Guiada pela inteligibilidade de um corpo-memória que recupera o passado revelando sua latência no presente, em Jamais o fogo nunca (2007) Diamela Eltit propõe, de forma li terariamente política, uma releitura histórica da ditatura milita chilena de um modo, fundamentalmente, feminino. Neste romance, uma mulher sem nome rememora episódios passados ao mesmo tempo em que examina a banalidade do presente uma liderança militante autoritária. Por que interpela o desaparecimento de um projeto político, revelando suas contradições internas, Jamais o fogo nunca expõe a relação dialética que une passado e presente para retirar do silenciamento a hierarquia de gênero que estruturou tanto o moralismo do Estado quanto as organizações militantes. Ao aproximar-se da ditadura militar por meio do escrutínio da masculina militância, o romance questiona a falocêntrica racionalidade elabora um tipo de aproximacão ao passado que, como colocou Walter Benjamin nas teses que de Históra" (1940), alia rememoraçäo e redença. Neste artigo, interessa-nos investigar em que medida esse gesto - que coloca em xeque os lugares hegemônicos do saber - possibilita ao romance de Eltit postar-se como uma instância dissensual de pensamento.

PALAVRAS-CHAVE: Diamela Eltit; Jamais o fogo nunca; Walter Benjamin; Ditadura; Mulher.
* ccamilacarvalho45@gmail.com Mestre e doutoranda em Teoria da Literatura e Literatura Comparada pela Universidade Federal de Minas Gerais (UFMG). É bolsista FAPEMIG.

RESUMEN: Guiada por la inteligibilidad de un cuerpo-memoria que recupera el pasado revelando su latencia en el presente, en Jamás el fuego nunca (2007), Diamela Eltit propone, de forma literariamente política, una nueva lectura histórica de la dictadura militar chilena de una manera, fundamentalmente, femenina. En esta novela, una mujer sin nombre recuerda episodios pasados mientras examina la banalidad del presente que comparte con su compañero, la imagen degradada de un líder militante autoritario. Por medio de ese cuerpo-ruina, que interroga la desaparición de un proyecto político revelando sus contradicciones internas, Jamás el fuego nunca expone la dialéctica relación que une pasado e presente para retirar del silenciamiento la jerarquía de género que estructuraba tanto el moralismo estatal como las organizaciones militantes. Al aproximarse de la dictadura por medio del escrutinio de la masculina militancia, la novela cuestiona la racionalidad falocéntrica y elabora un tipo de aproximación al pasado que como colocó Walter Benjamin en las tesis que l concepto de Historia" (1940), combina (1940), combina rememoración y redención. En este articulo nos interesa investigar en qué medida ese gesto - que pone en jaque los lugares hegemónicos del conocimiento - posibilita a la novela de Eltit presentarse cómo una instancia no consensual del pensamiento.

PALABRAS-CLAVE: Diamela Eltit; Jamás el fuego nunca; Walter Benjamin; Dictadura; Mujer. 
Um anjo que parece estar na iminência de afastar-se de algo que encara fixamente; que volta as costas ao horizonte vindouro. Um anjo cujas asas estão travadas por uma tempestade que sopra do paraíso e o impede de recolher os escombros que se acumulam diante de seus pés: uma única catástrofe; um a montoado de corpos do qual não desvia o olhar. Um anjo que luta contra essa tempestade e resiste. Assim deve parecer o anjo da História, nos dirá Walter Benja min. Em Jamais o fogo nunca (2007), primeiro romance de Diamela Eltit publicado no Brasil, o anjo da História tem corpo de mulher. Nesta narrativa - guiada por uma inteligibilidade corporal que recupera o passado revelando sua la tência no presente - a autora edifica, de forma literariamente política, uma releitura histórica da ditatura militar chilena. Tomando como ponto de partida a imagem benjaminiana, interessa-nos, neste artigo, especular de que maneira a escolha da voz narrativa ao oportunizar um modo específico de aproximação do passado, possibilita ao romance postar-se como uma instância dissensual de pensamento.

Nesta narrativa em primeira pessoa, fragmentada completamente alheia à linearidade, uma ex-militante sem nome rememora episódios passados, ao mesmo tempo em que avalia a mediocridade do presente que compartilha com seu companheiro, um líder militante a utoritário. O compromisso ideológico inflexível lhes custara a morte do único filho. A clandestinidade impedira o casal de levar o menino a um hospital durante uma crise asmática, que, então, faleceu - diante dos pais - num quarto pequeno e insólito; o mesmo quarto onde, agora, a narradora revisita seu passado e avalia o colapsado presente que experimentam. Apropriando-se da paradoxal condição à qual Pinochet relegou milhares de desaparecidos - esse espaço de suspensão entre a vida e a morte -, Eltit edifica um corpo-ruína que, ao interpelar o desaparecimento de um projeto político revelando suas contradições internas, expõe a relação dialética que une passado e presente para evidenciar a hierarquia de gênero na qual fundou-se tanto o moralismo do Estado quanto a estrutura militante. Mantendo-se em constante vigília, essa mulher crava seu olhar nos corpos-ruína que se amontoam no passado - o seu próprio, o de seu companheiro e o de seu filho morto - e, por meio dessa exumação simbólica, especula como se desenvolveu o processo que convertera um projeto político de libertação num avatar velado do inimigo; numa estrutura tão burocrática, hierarquizada e milita rizada quanto aquela que intentavam combater. Feito o anjo benja miniano, ela dá as costas ao futuro e, cravada no presente, orienta-se pelo passado. 
1. Neste artigo optamos por utilizar a tradução das teses elaborada por Jeanne Marie Gagnebin e Marcos Lutz Müller para o livro Walter Benjamin: aviso de incêndio: uma leitura das teses Sobre o conceito de historia (2005), de Michel Lowy. Duas sáo as razoes desta ser uma tradução direta do origina lemão (Über den Begriff der Geschichte). em segundo lugar,

por ser aquela utilizada por Löwy,

autor ao qual recorremos algumas

vezes ao longo deste texto. Assim esclarecemos que o uso do apud nos casos em que citamos o texto de Benjamin não se dev à impossibilidade de consultar a fonte primária, publicada em português pela editora Brasiliense, mas à escolha consciente de não a utilizar. De todo modo, esta ultima encontra-se nas referências bibliográficas deste artigo.

2. Este é, por exemplo, o entendimento de Michel Löwy que no livro citado na nota anterior, escreve: "essa Tese resume 'como um foco' o conjunto do documento" (2005, p.87).
Das inúmeras alegorias que compõem o célebre "Sobre o conceito de História”,' o Angelus Novus, de Paul Klee, figura central da Tese IX, é certamente a mais conhecida. A razão dessa popularidade talvez resida em seu poder de síntese. ${ }^{2}$ A nona tese resume de modo muito eficiente as questões centrais que guiam todo o documento. Nele, Benjamin recla ma por uma História que refute, de modo absoluto, a ideia de um passado encerrado, exitoso e implacável. Uma História que não se deixe seduzir pelo progresso por vir. Uma História que não se afaste do presente; que sabe ser a rememoração do passado o único instrumento capaz de redimir o tempo-do-agora Uma História consciente de que não há futuro possível sem essa redenção. Uma História que interrompa sua continuidade suposta mente inevitável; que puxe os freios da locomotiva do bárbaro progresso; que reconheça a imagem autêntica do passado num instante de perigo. Uma História que não ignore esse instante de perigo.

É “a vontade de compreender as causas profundas da derrota do movimento operário alemão diante do fascismo hitlerista”, escreve Michel Löwy (2005, p. 101), o ponto de partida de Benjamin para a escrita das Teses. Nesta sua empreitada, o filósofo alemão não se furta a confrontar e apontar a contribuição crucial da esquerda para a vitória inequívoca do inimigo. Embora fossem duas perspectivas políticas notadamente distintas - cujas discordâncias eram suficientes para localizá-las em polos quase opostos -, nem a socialdemocracia, nem o comunismo soviético escaparam ao olhar crítico do filósofo No que diz respeito ao modo como compreendiam a História, diria Benjamin, essas duas vertentes estavam bem mais próximas do que gostariam: a ncoraram, a mbas, suas estratégias de ação e de oposição ao crescente fascismo num mesmo pressuposto - num "aliado" comum -, o irrefreável progresso. Comunistas e socialdemocratas incorriam, portanto, no mesmo erro e, ao acreditar ser sua vitória uma decorrência inevitável do contínuo da História, converteram-se, ambos, no tipo mais fraco de opositor. Subestimaram a força de seu adversário. ${ }^{3}$ Ignoraram o instante de perigo. Mantiveram-se cativos a uma forma de apreensão equivocada da História; um erro determina nte que o transcurso dos fatos não deixaria de evidenciar.

Contrapondo-se ao marxismo evolucionista, Benjamin propõe que uma articulação histórica efetiva não pode se furtar a dois gestos essenciais: a rememoração e a redenção. No horizonte de seu pensamento, a interlocução entre passado e presente é, portanto, inegociável: "a verdadeira imagem do passado passa célere e furtiva" (BENJAMIN apud LÖWY, 2005, p. 62), ele escreve na
3. Essa é uma questão exposta muito claramente na Tese VIII, na qual se consiste, não por último, em que seus adversários $o$ afrontem em nome do progresso como se este fosse uma norma histórica" (BENJAMIN apud LÖWY, 2005, p.85, itálico nosso).
EM TESE
BELO HORIZONTE
v. 26
N. 3
SET.-DEZ. 2020
CARVALHO. 0 anjo da história tem corpo de mulher
p. 262-279 
quinta tese. Reconhecível apenas por um instante, esse momento fugaz em que irrompe no tempo-do-agora, a autêntica imagem "do que já foi" é aquela que, feito um relâmpago, passa. É por compreender a História conjugando-a à memória, ${ }^{4}$ que Benja min se distancia completamente da leitura marxista elaborada pela esquerda e, consequentemente, de seu impulso de enxergar o progresso com otimismo: o que a rememoração do passado - ao expor os sucessivos massacres - atesta é, antes, sua essência de barbárie.

Em Jamais o fogo nunca, são ta mbém essas duas formas de compreender a História que se materializam nos corpos das personagens em contínuo conflito: historicismo progressista, materialismo dialético. A construção desse enfrentamento se perfaz tanto no âmbito discursivo isto é, nas reflexões e questionamentos elaborados por essa voz feminina - quanto naquele propriamente corpóreo: a posição que ocupam na cama, a destreza ou a dificuldade com que se movimentam, o modo como comem, dormem ou mantêm-se em vigília:

Você pega o chocola te e o divide igualita ria mente. Gostamos muito de chocolate, eu mais, mais, seu sabor, sua perambulação lenta e cuidadosa pelas gengivas, pelo côncavo palato, eu nunca mor do, nunca, em vez disso o derreto na boca até que minha saliva esteja impregnada e dilato o momento em que ele desliza garganta adentro. Você, em compensação, vai rápido com o pedaço de chocolate, tem fome logo pega um dos biscoitos que range no embate dos seus dentes. Eu viro o olhar, não quero interferir nos seus ruídos exagerados e por isso olho para o chão e noto, de imediato, que seria preciso encerar as tábuas, que já chegou a hora, que você tem que encerar porque faz quanto tempo desde a última vez que você passou a palha de aço, a mais grossa que eu encontrei, e você o fez de mau humor, carregando todo o seu peso na palha para extrair das tábuas as aderências desagradáveis que acabaram se convertendo em uma considerável sujeira aglomerada. Então você desabou, parecia sensivelmente diminuído, você se deitou exausto na cama [...]. Então você me olhou com uma expressão irônica, burlesca, eu sabia que, com seus lábios oscilando entre a careta e a mordacidade de um sorriso, você expressava que era culpa minha, a cera, o cheiro, o seu desgaste. Você me dizia, com aquela careta-sorriso, que você era a verdadeira vítima de uma decisão idiota e assim ressaltava sua absoluta indiferença diante do estado decadente das tábuas. (ELTIT, 2017, p. 92-93, itálicos nossos).

Enquanto a mulher se posta altiva e determinada a encarar o passado e o presente, seu interlocutor dá as costas a essa sucessão de barbáries; incorpora sua "inevitável" derrota, e se compraz, resignado, com seu encarceramento para fora da História:
4. Essa relação de interdependência étre a rememoração e a redençãa dialético de Benjamin. Tornase, então, imperativo esclarecer que, com esse gesto, o filósofo que, com esse gesto, o filóso
reela o conceito criado pela teoria marxista e, muito embora as duas formulações se aproximem em alguns pontos, em outros distanciam-se quase que completamente. $\mathrm{O}$ exemplo mais claro desse distanciamento repousa no diálogo que, do ponto de vista benjaminiano, o conceito estabelece com a teologia. As limitações deste artigo, contudo, não nos permite dedicar atenção a esta diferença e, desse modo, limitamo-nos a sinalizar que, neste texto, entendemos o termo conforme propôs Walter Benjamin GAGNEBIN, 2018. 
5. Neste artigo utilizamos a tradução de Julián Fuks para a edição brasileira publicada pela editora bibliográficas indicamos a diça original.
Depois de um século eu observo você agora dormindo ou acordado, pensando sem nenhum horizonte, estendido na cama A cama e você, esse é o pacto, os lençóis e meu travesseiro, o século inteiro, os mil anos desmoronados. Ali você fica, no quarto, recolhido, com seu crânio (sua caveira) entre o travesseiro e o lençol, deitado. (ELTIT, 2017, p. 142-143, itálico nosso). ${ }^{5}$

Ciente do risco - sempre iminente - desses gestos diletantes, a mulher não cessa de confrontar a impostura de seu interlocutor. A cena em que expõe ao companheiro sua discordância diante de uma frase, desenha, de modo muito claro, esse enfrenta mento contínuo. Voltando ao quarto, ela senta-se na cama, e, no intuito de organizar algumas imagens que a rodeiam, "imagens obsoletas que provêm de um século cujo término ainda ressoa”, tenta iniciar com ele "um intercâmbio pacífico" (ELTIT, 2017, p. 22):

Faz mais de um século, eu lhe digo, mil anos pelo menos, que me ronda a discordância de uma frase, a mesma que anotei então subjugada pela perfeição de seu traçado. No entanto, continuo, continha uma a mbiguidade, qual, você pergunta, que ambiguidade, escute com atenção, eu lhe digo: "Os operários não têm pátria. Não se pode arrebatar aquilo que eles não possuem." Ah, você me diz, chega, chega, você me diz, a té quando, você murmura [...]. Não tem nenhuma a mbiguidade, você diz. A frase é direta, real, compreensível, certeira. [...] É enganosa, eu digo, a frase, permite interpretações demais, utiliza a palavra pátria e isso abre uma aresta perigosamente sentimental, trapaceira, na medida em que a reconhece, a pátria, eu digo. (ELTIT, 2017, p. 24-25)

Aqui, seu método faz lembrar aquele benjaminiano. Por meio da rememoração, ela confronta o purismo teórico que orientou a luta militante. Uma frase. Uma ruína. Um resto de diretriz que ela recupera e ressignifica. Pátria. Uma palavra cara ao desgoverno de Pinochet. A palavra-máscara que cobriu a face importada do golpe. Não por acaso a discordância da narradora gira em torno da legitimação - ainda que pelo avesso - desse signo. O reconhecimento da Pátria funciona, então, como uma metonímia: por meio desse resíduo - especifica mente desse - a mulher insinua o modo como a resistência incorporou a lógica do inimigo.

Fracassaram. O presente insólito evidencia a cada segundo: fracassaram. Mas continuarão fracassando, permanecerão apagados se não revisita rem essa derrota; se não remexerem seus escombros; se não compreenderem suas razões. Rememorar o passado para redimir o presente, lembremo-nos de Benjamin. Essa é a tarefa da História que não prescinde da dialética. Simbolicamente, essa frase é o que sobrou de toda uma orientação teórica
6. O golpe de Estado comandado por Pinochet, cuja motivação principal era a instauração de uma política neoliberal austera, foi diretamente financiado pelos Estados Unidos da América. Assim, para compreender os contornos especificos da

ditadura chilena - bem como de seus ecos no presente - $\mathrm{e}$ necessário náo perder de vista o assédio economico inaugurado pelo general e seus Chicago boys. Assédio este que - vale lembrar permanece em voga. Sobre o tema cf. KLEIN, 2008. 
7. Referimo-nos ao autômato jogador de xadrez, alegoria central da primeira Tese.

8. A frase é uma citação direta do Manifesto Comunista de Karl Marx
e Friedrich Engels.

9. A esse respeito, escreve Leandro Konder em seu Walter Benjamin: o marxismo da melancolia (1999, p. 49): "É em Rua de mão única uso para as citações: em vez de uso para as citaçoes: em vez de para demonstrar erudição, ele aproveita o prestígio que elas adquiriram para surpreender seu leitor, sacudindo-o do torpor em que o colocaram os hábitos mentais cultivados pela ideologia conservadora dominante nas nossas sociedades"; e cita Benjamin "Citações, no meu trabalho, são como salteadores de estrada, que assaltam, armados, os viajantes, para roubar-lhes as convicções" (BENJAMIN apud KONDER, 1999, p. 49). No romance, por se tratar do questionamento da racionalidade militante, o uso da citação pare operar no
Benjamin.

10. No corpo do texto, os trechos em itálico e entre parênteses foram retirados da citação direta à qual a análise faz referência. que, acolhida sem qualquer ressalva, fora convertida pela militância num autômato - para recuperar uma outra alegoria benjaminiana $-{ }^{7}$ cuja vitória estava, de antemão, garantida. "Estáva mos esperando a chegada inescapável da história" (ELTIT, 2007, p. 38). Mas, ainda que no passado tenha anotado o fragmento subjugada pela perfeição de seu traçado; no presente - a mparada pela necessária distância temporal que as revisões exigem -, essa mulher não hesita em submetê-lo ao escrutínio. Enganosa, ela diz, a frase. É, portanto, a pertinência de um purismo teórico que, por meio dessa citação, ${ }^{8}$ um outro eco benja miniano, ${ }^{9}$ ela interpela e questiona.

O homem, ao contrário, mantém-se enovelado numa concepção equívoca e insiste numa defesa inócua. Ignora as razões de seu evidente fracasso. Recusa-se, num primeiro momento, a participar dessa escavação simbólica (Ah, você me diz, chega, chega, você me diz, até quando, você murmura $)^{10}$ mas, em seguida, não se furta de tentar a nular a legitimidade dessa revisão (Não tem nenhuma ambiguidade, você diz. A frase é direta, real, compreensível, certeira) A insubmissão de uma mirada crítica e a obediência de um olhar conformista: de um lado, uma leitura capaz de enxergar a heterogeneidade constitutiva do tempo; de outro, a crença em sua linearidade irremediável. A contingência e o fatalismo. Diante dessa resignação, desse gesto despropositado, ela reage de modo ainda mais consciente:

Mas este é um dia de um século diferente, de uma época carente de marcas, um século que não nos pertence e que, no entanto, somos obrigados a experimentar, e neste século parece tudo irreal ou prescindível, sim, prescindível. Não é assim, você me diz, você sabe, nós analisamos bem, nos empenhamos em dimensionar o efeito de cada uma das palavras, fizemos isso exaustivamente a té que a célula entendeu, se fez especialista, irrepreensível, orgânica. Qual célula?, eu pergunto, confusa, qual de todas as células? [...] [V]ocê sabe, ta nto qua nto eu, que a sentença aparentemente perfeita se prestava a cair no que tanto temíamos, num reformismo que podia aniquilar os presságios de um século que terminou sem pena nem glória, sem glória, especialmente assim, cativo em seu próprio reformismo, inclusive você, que parecia incorruptível, teve que ceder, você sabe, você cedeu, se entregou às alucinações que o século ia produzindo para perfurar a si mesmo. (ELTIT, 2017, p. 25-26, itálicos nossos).

Reescrever a História a partir dos restos. É o que faz essa mulher. Um corpo-memória que se nega a consentir com o próprio apaga mento. Um corpo-memória que expõe sua potência política quando instaura um dissenso; quando reconfigura o passado no presente. Um corpo-memória que sabe que não estará salvo, que não poderá 
descansar enqua nto não redimir o tempo-do-agora: "Mas eu não posso, não sei como dormir se não recupero a parte perdida, se não escapo do buraco nefasto do tempo que preciso atrair" (ELTIT, 2017, p. 15, itálico nosso). Um corpo-memória, enfim, que inspeciona avidamente cada uma das peças que edificaram sua derrota perseguindo uma questão fundamental: como terminaram, ela e seu companheiro, naquele quarto insólito?

Embora a maior parte da narrativa se desenvolva no interior desse a mbiente asfixiante - um estra nho cômodo pequeno, precário, cujas janelas quase sempre fechadas os afasta do mundo exterior -, é um outro espaço, apresentado logo na primeira frase do romance, que impulsiona as rememorações dessa mulher sem nome: "Estamos jogados na cama, entregues à legitimidade de um descanso que merecemos" (ELTIT, 2017, p. 13). Um espaço ainda mais desconcertante: a cama insólita que dividem; a sua ca ma, como repete inúmeras vezes essa voz feminina. No romance, a ca ma é o espaço-gatilho que torna inevitável a realização desse trabalho de memória.

De modo lapidar, esta imagem potencializa cada uma das dimensões simbólicas que a rememoração interpela. A cama, sobretudo quando habitada por um casal, é um território privilegiado da sexualidade. Removendo desse espaço qualquer dose de erotismo, Eltit, a um só tempo, apropria-se e subverte esse imaginário. A escolha por uma cama privada por completo do desejo, não é, portanto, fortuita. Sua frigidez é o que a converte num espaço-gatilho; um espaço-símbolo mais que pertinente para uma rememoração cujo objetivo é afrontar cada um dos contornos que compõem a insistente - e histórica dominação masculina:

Você perdeu, sim, perdeu o controle que as suas posições tinham alcançado, foi derrubado pelos argumentos dos seus adversários. Eu concordava com o grupo dominante, tinha entrado em conluio com as razões que você não compartilhava porque eram, como você disse, inconducentes. Atentei para essa palavra, eu já tinha ouvido "inconducente" vezes demais da sua boca, e soube que era uma armadilha, um termo que você propunha com o mero objetivo de inibir. Entendi que eu tinha que me opor. [...] Eu tinha que anulá-la, sua autoridade, a legitimidade forçada que você imprimia. Uma palavra-máscara que intimidava. É claro que eu não podia confrontar diretamente os seus pressupostos. Tirei minhas próprias conclusões, me agarrei aos termos mais simples para me distanciar do seu hábito, da sua mania de se apoiar numa densidade com a qual você dramatizava cada uma das suas intervenções. Por fim me dobrei ao grupo que buscava o fim de uma tirania sem objeto. [...] Dessa maneira interrompi 
o caudal de ideias reformistas com as quais você pretendia nos manter cativos. (ELTIT, 2017, p. 28-29, itálicos nossos).

Desta crítica central irradiam todas as outras. Durante todo o período em que militaram juntos, esta mulher permaneceu subjugada à opressão de seu companheiro, a personificação de uma lidera nça autoritária que o tempo degenerou completamente. Esse corpo masculino degradado, a cada instante mais e mais decadente, depende, agora, dos cuidados da mulher. Por meio de um exame minucioso, voltando-se para esse homem de modo quase microscópico, ela tateia os erros cometidos pela resistência. Privilegia os eventos menores; recupera cada um dos instantes "desprezíveis". Assim opera esse a njo da História que tem forma de mulher: aproxima-se do corpo, explora-o a té o limite das suas relações fisioló gicas, para em seguida, a fastar-se e inseri-lo num quadro a nalítico que o extrapola:

Volto ao quarto e, com um tom de voz excessivamente entusiasmado, aviso que já está na hora, que você tem que se alimentar. Passo o arroz, você se levanta parcialmente, cansado, com uma severidade que me preocupa. Você come quase sentado na cama. Eu o observo distraída diante de uma cerimônia já naturalizada. Lembro como, no século que de certo modo nos pertencia, eu observava com assombro as suas sentenças diante do a to alimentício [...]. Podíamos consumir apenas o necessário para os nossos fins. Não convinha, assim você disse, entregar-se à comida, fazer dela um lugar que acabava por ocultar o impacto da fome. A fome, eu sei, tinha para você uma função A fome, você apregoou, era um estado que aprofundava o rigor e nos permitia um trabalho concreto e sustentável. Mas nunca, nunca a saciedade, isso não, você ga rantia, porque dessa maneira se instalava uma modorra que nos obrigava a adiar o objetivo. Você odiava a modorra, preferindo, ainda que no desconforto, a fome. Eu mesma pude comprovar, fiz isso quando me entreguei à glorificação dos alimentos, ao seu excesso gorduroso. Você a odiava, a gordura, o corpo gorduroso e seu brilho. Um corpo arredondado por camadas de uma gordura liquefeita que produzia aquela languidez que adiava a agilidade, aquela agilidade que você pedia para a célula e que, se não se adequava ao seu desejo, nós tínhamos que refazer com outros corpos disponiveis, famintos e enérgicos. Olho você na cama, vejo você obstinado em desalojar a fome, a primeira, a fome óbvia que o invade. Você come sem censura, de um jeito que não pode senão me resultar incômodo. (ELTIT, 2017, p. 22-23, itálicos nossos).

É por meio de uma reconciliação com a materialidade do corpo, suas dimensões sensoriais e afetivas, que ela reelabora e reconfigura o que já foi e o que agora é. Diante desse corpo de líder degradado, ela rememora a racionalidade exagerada na qual ele apoiou cada um dos 
afetos de seus "subordinados". Nesta cena, o paradoxo que se edifica pela comparação entre aquilo que um dia ele apregoou e o que agora realiza expõe a ineficácia de seu método: a decisão de avaliar objetivamente cada um dos movimentos da célula. Ao ignorar o corpo e seus a fetos; ao negligenciar a potência do sensível; ao racionalizar, enfim, todo e qualquer impulso de vitalidade, a resistência pensava se blindar dos desvios que adiariam o objetivo. Esta decisão, no entanto, conforma-se, agora, como o seu maior equívoco. $\mathrm{O}$ fracasso que experimentam - uma derrota que ela especula ter sido facilitada por esse excesso de objetividade - expõe o modo como foram esmagados e engolidos pelo tempo: naturalizam, hoje, tudo aquilo que, num século que de certo modo os pertencia, eles pensavam combater.

Mescla ndo dor e indolência, como bem sinaliza Julián Fuks no prefácio do romance, a reflexão dessa mulher conjuga à contraditória estrutura militante, o fracasso político e a figura alquebrada e agonizante desse corpo masculino. A imagem desse homem decadente sintetiza a derrota experimentada pela militância no passado. E, assim sendo, nos parece pertinente afirmar que, em Jamais o fogo nunca, o fracasso político da resistência é indissociável de uma crise da masculinidade. Um declínio que a ficção edifica. Uma queda à qual o romance dá forma. Propondo uma alternativa à masculina configuração vigente, Eltit elabora uma outra "cartografia" cujo princípio é, essencialmente, a demarcação do contorno obsoleto do patriarcado. Questionamento de uma lógica falocêntrica, em diversos sentidos, em suas várias dimensões simbólicas, é o que Jamais o fogo nunca se empenha em edificar.

Enquanto a configuração a mbígua desses corpos evoca uma fissura do passado - a máquina de desaparecimentos à qual Pinochet deu forma -;i11 sua contínua fricção sugere uma maneira de articulá-lo. Ela, a mirada atenta; ele, os olhos cerrados. Ela, a imagem alegórica de um trabalho de memória tão dolorido quanto necessário, que, em constante vigília, cuida de corpos decadentes - vivos e mortos. Ele, a materialização de um presente displicente. Um presente em ruína que conserva, a despeito do colapso de sua arcaica superficie, um tom autoritário; uma tentativa de dominação tão risível qua nto persistente. Um presente que incorpora, literalmente, cada uma das dores que um passado mal lido lhe reserva; mas que, a despeito disso, insiste em demonstrar sua "lógica"; em tentar manter sob seu controle, a perspectiva. ${ }^{12}$

"Mas agora este tempo final me pertence" (ELTIT, 2017, p. 91, itálico nosso), ela diz. Nesse "agora" feminino que
11. Aqui, referimo-nos ao fato de eresses corposina uma Feitos os milhares de

desaparecidos - que, apesar de

não estarem mais vivos, não

podem ser considerados como

mortos, uma vez que seu óbito

não pôde ser oficializado -, as

personagens do romance habitam esse espaço de suspensão entre a vida e a morte.

12. Num trecho em que analisa $o$ comportamento do companheiro durante as parcas caminhadas que realizam juntos, a narrador demonstra, simbolicamente, esse desejo de controle quando comenta sobre a insistência do homem em sair sem o casaco: "Você saiu, claro, desagasalhado, você sempre faz isso, como se quisesse testar a sua propria resistencia ou talvez explorar no seu corpo os sinais de uma leve adversidade" (ELTIT, 2017, p. 91 itálicos nossos) 
a memória reconfigura, ele já não pode exercer nenhum tipo de domínio. Não mais. Precisa dela, está subjugado a ela. Ao seu escrutínio, à sua crítica, ao seu olhar profundamente histórico e dialético. Uma fricção de corpos que perfila uma imagem vigorosa de nosso tempo. Decadente, mesquinho e fracassado. Preso a certezas tão "técnicas" qua nto ineficientes. Um tempo que carece de um efetivo trabalho de memória; que assim como esse corpo masculino, se quiser sobreviver, não pode prescindir de uma revisão crítica da História.

Em Jamais o fogo nunca essa revisão é elaborada desde um ponto de vista feminino. É precisamente essa escolha que dá ao romance o tom de sua crítica. No imaginário social, a mulher é, não raro, associada à imprudência e à inobservância. Uma lógica machista que, mascarando a própria misoginia com a disparatada suposição de sermos nós mais propensas a cometer atos irrefletidos ou guiados pela impulsividade, perfila meca nismos de dominação que se "autojustificam”. São raras as verdadeiras manifestações de racionalidade feminina. Logo, é natural que sua insurgência desperte suspeitas: submeter - sempre e continuamente - à prova sua consistência e viabilidade não é, portanto, nada além de um gesto de prudência e precaução.
Jamais o fogo nunca confronta - e de um modo inusitadamente vigoroso - esse absurdo pressuposto. Não pelo fato de ser guiado por uma voz feminina obstinada e tampouco por desenhar, em contraposição, um homem fragilizado e impotente. Contentar-se com a imagem de uma mulher logicamente ina tacável e que, em nenhuma instância, corresponda a esse degenerado raciocínio não seria, ainda que pelo avesso, legitimá-lo? Jamais o fogo nunca confronta esse absurdo pressuposto porque se exime de tentar provar sua incoerência, edificando uma personagem feminina cuja conduta é retilínea, blindada e inquestionável; porque, ao contrário, presta-se a enfrentá-lo dina mitando o seu princípio: a valorização - e mesmo a possibilidade de existência - de uma racionalidade fria, numérica, neutra e destituída de afetações. Negando-se, veementemente, a reconhecer essa lógica, por meio de um questiona mento acerca da configuração disso que se entende por inteligibilidade, o romance não só traz à tona os submersos mecanismos de opressão $e$ assédio que permitem a esse absurdo pressuposto manter-se de pé, como também, sugere ser esta valorização o que desencadeia uma série de consequências desastrosas. Coloca, portanto, em xeque essa descabida relação de causa e efeito sem, contudo, render-se a soluções fáceis. Critica o pensamento falocêntrico ao mesmo tempo em que se mantém distante das dicotomias simplistas. 
Não por acaso é a um vestido vermelho que, de modo brilhante, Eltit recorre para elaborar essa crítica. A imagem é potente porque aglutina as três grandes questões do romance: a hierarquia de gênero que desvela a aproximação incômoda entre governo e militância; a precária "razão masculina" na qual esta última manteve-se presa; e o imperativo econômico, orientado pela devoção ao mercado e ao consumo, que marcaram tanto o regime Pinochet quanto o período posterior. Nesse sentido, Oliveira-Williams (2010) tem razão quando afirma que esta é uma das passagens mais enigmáticas e irônicas da narrativa.

Um relato que recusa binarismos. O único trecho em que o desejo ocupa o lugar central. Uma cena que, explorando esse signo à exaustão, não se inibe e parece questionar: não seria a constante repressão dos fluxos desejantes aquilo que, longe de a niquilar, os mantém em estado de latência? Não seria essa coerção o que acaba por oportunizar que o desejo se manifeste sob a forma do consumo alienado? Não seria, justa mente, a negligência do afeto o que desenha essa relação de sinonímia como sendo a única possível? Uma cena ambígua que de modo absolutamente desconcertante expõe, a um só tempo, a configuração ardilosa do desejo de consumo e sua contraditória potência redentora:
Lembro que saí à rua num ato completamente desatinado, rompendo qualquer lógica de segurança. Saí à rua, caminhei por calçadas expondo minha figura já abertamente deformada. E de repente experimentei o impacto diante daquele vestido que, ainda que eu tenha me negado a reconhecer, ocupou inteiramente meu desejo e se apoderou da minha mente em ondas desejantes e secretas. O vestido que deteve meus passos na rua e me confrontou à vitrine e, subitamente, eu quis, eu quis o vestido, a mei o vestido, me apaixonei de imediato. Seu tecido, seu corte, seu desenho e a urgente, enlouquecida necessidade de comprar o vestido, de me vestir, exibi-lo em mim, comer o vestido, devorá-lo inteiramente, gastar no tecido, no desenho, no corte, me entregar sem pudor, alheia a qualquer átomo de culpa, a um prazer bacante e absoluto com a exterioridade, a superfície mais daninha a que eu podia entregar meu corpo. Renunciar à renúncia que fizemos nos primeiros anos em que nos refugiamos de uma vez e para sempre a trás de um desprezo consistente. Lutei para tirar as calças desorbitadas, a blusa amorfa, o colete, queimá-los, a niquilá-los na potência devastadora de uma fogueira e acudir cega ou virginalmente em direção ao vestido para renascer ou ressurgir ou evitar um destino marcado pelo excesso total de corpo, pela ausência de contornos, um corpo que tinha experimentado a história nua ou real, uma história que em toda extensão de seu tempo incomensurável teve que se dedicar sempre a aniquilar. Assumimos isso, tomamos a direção inamovível de uma escassez realmente militante, a ustera, os dois, sua austeridade, minha austeridade. A não 
ser naquele dia. O que aconteceu naquele dia? O que aconteceu comigo ou conosco para que desencadeasse em mim a alienação de uma vitrine cosmética e reprovável? O que aconteceu em mim para que eu parasse e me entregasse a um desejo infame que rompeu a qualidade mais pétrea dos meus ossos? A imagem do vestido os debilitou, de certo modo, os desprezou: meus ossos aos meus ossos. Meu olhar ávido, um desejo que explodiu imprevisível, que rompeu limites, cada uma das estratégias que tive ou tivemos que construir e que possibilitou que os ossos rodassem feito cacos rumo à mais incrivel alienação. Sim, eu mesma, especializada em linguística e absolutamente consciente da rejeição como procedimento imperativo e liberador, me vi diante de uma vitrine que me convocava em direção a um vestido tortuoso, desenhado para seduzir e fugir dos avatares de uma história, um vestido que ia me liberar da infâmia, que ia me distrair de um poder que finalmente tinha me perfurado até a medula dos ossos. Sim, um poder que tinha ofendido a única consistência do corpo, que, sabíamos, era primordialmente ósseo. (ELTIT, 2017, p. 112-114, itálicos nossos).

Uma vitrine, a expressão mais eloquente do capital. Uma fantasmagoria, a síntese da fugacidade e da frivolidade do consumo. Uma indumentária "especificamente" feminina. O desejo reprimido convertido na necessidade, quase irrefreável, de consumir um vestido. Vermelho. Um vestido vermelho que sintetiza e expõe, pelo menos, duas questões fundamentais. A primeira, refere-se à avidez da na rradora por recuperar sua figura já abertamente deformada. Podería mos nos perguntar, então, de que deformação se trata: a qual imagem ela se refere? Mulher e militância, a rriscamos. A deformação do papel que deve exercer uma mulher na militância. "Eu tinha me transformado numa não, não, nunca oficializada subalterna sua" (ELTIT, 2017, p. 112), ela recorda pouco antes de relatar esse episódio. Seu "prestígio como a nalista", sua passagem "indiscutível e memorável por cada uma das escolas de quadros", toda sua "experiência prolongada e aguda no ramo da linguística” (ELTIT, 2017, p. 112) deformadas por uma lógica masculina. Ignoradas, as suas habilidades; incompatíveis com o papel subalterno que era obrigada a desempenhar em cada uma das células. A paixão pelo vestido, seu impulso de devorá-lo inteiramente, de exibi-lo em seu corpo é, antes de tudo, a manifestação do desejo de marcar seu espaço como mulher; de negar esse apagamento; de evidenciar sua importância sem prescindir de seu corpo de mulher. De modo muito potente, a cena desenha a dimensão do domínio a que fora submetida a narradora: a repressão sofrida por esse corpo feminino dentro do a mbiente da resistência fora tão violenta mente intensa que, não podendo mais suportá-la, a analista qualificada se rende àquilo que combate porque precisa converter esse silenciamento em grito. 
Um gesto, sem dúvida, a mbíguo: se o aproxima mos ao tipo de sociedade que, de um lado, o Estado barbaramente intentava construir e que, de outro, a oposição se empenhava em combater, é imperativo levar em conta seu contorno de subordinação e de sujeição; mas, se, ao contrário, o conjugamos às imposições e restrições impostas a essa mulher pela organização militante, torna-se igualmente necessário reconhecê-lo como um ato de transgressão e de libertação.

A segunda questão, também funda mental e inseparável desta primeira, relaciona-se à crítica da racionalidade militante que não cessou de reprimir todo e qualquer gesto que se afastasse das premissas de um projeto previamente estabelecido. Um projeto que não admitia nem desvios, nem concessões; que ignorou a dimensão do desejo e desprezou o corpo e seus movimentos vitais Uma racionalidade - ela parece sugerir - que a militância incorporou de seu opositor uma vez que, como ele, não hesitou em reprimir, controlar, uniformizar e transformar o corpo - sobretudo o seu corpo - num dispositivo totalmente disforme (Lutei para tirar as calças desorbitadas, a blusa amorfa, o colete, queimá-los, aniquilá-los na potência devastadora de uma fogueira); num maquiná rio pragmático e programado cujos movimentos deveriam ser rigorosamente calculados e precisos.
A pergunta que guia essa rememoração - o que aconteceu? - não é respondida diretamente, mas está implícita em sua reflexão: desejo é o motor do consumo. Talvez tenha sido isso o que aconteceu. Ao descuidar-se por completo de uma dimensão afetiva; ao reduzir a vida à pura racionalidade, a célula abriu a fenda em que se alojou seu fracasso. Reprimindo os fluxos desejantes, a resistência os manteve em estado de latência e possibilitou que, nesta cena emblemática, sua explosão tomasse a forma do consumo e da alienação. Negando-se em discutir a potência do circuito dos afetos, a estrutura programática militante criou, em certa medida, as condições que permitira $m$ ao inimigo definir e direcionar o desejo dos corpos como melhor the conviesse (abriram em mim o horizonte de um desejo que tínhamos proibido).

Mas, se é o questiona mento do absurdo pressuposto de que a mulher é mais propensa a cometer atos irrefletidos ou guiados pela impulsividade aquilo que Jamais o fogo nunca confronta, não seria um contrassenso a elaboração de uma cena na qual é justamente a mulher quem fraqueja diante de algo tão irrisório ou miserável como um tecido e um desenho? Tomar esse episódio tão somente como uma contradição ou como uma espécie de ato falho do romance é demasiado simplista. Para alcançarmos o modo como Eltit constrói esse confronto é preciso dar atenção ao que 
está submerso. A reflexão que a cena suscita extrapola o episódio narrado e, ao fazê-lo, exige que o leitor mimetize o gesto elaborado pela narradora durante todo o romance: para alcançar a dupla crítica que essa cena edifica, também nós não podemos prescindir de um exercício dialético.

Quando coloca em pauta a necessidade de não se desprezar uma dimensão afetiva; quando insinua ser essa negligência um erro importante da estrutura militante, a mulher, por meio da rememoração do passado, desvela o presente. $\mathrm{O}$ da narrativa e o nosso. Ao ponderar que, naquele dia, voltou-se para o vestido para renascer ou ressurgir ou evitar um destino marcado, ela não parece descrever uma cena que, hoje, somos nós quem protagonizamos? Como não questionar, diante desta rememoração, a maneira mecânica como temos replicado esse seu gesto desatinado? Ta mbém nós não abrimos a fenda por onde se aloja o fracasso a cada vez que depositamos no mercado - sobretudo naquele publicitário - a esperança da constituição de espaços mais diversos e inclusivos? Não temos, também nós, vestidos tortuosos que cremos serem capazes de nos liberar da infâmia? E que, no entanto, não fazem mais que nos distrair de um poder que nos perfura até a medula dos ossos? Mas, se estamos a té certo ponto conscientes disso, a que se deve nossa insistência nessas formas ilusórias de libertação?
É por esta razão que a configuração da cena nos parece especialmente potente: o rela to dessa mulher evoca a inseparabilidade entre a hierarquia de gênero - e, por extensão, sub-repticiamente, também aquela de raça e classe - e a estrutura do todo social. Submissões e sujeições criadas não somente pelas instâncias institucionais de poder - sejam elas autoritárias ou falsamente democráticas - mas, ta mbém, muitas vezes reproduzidas no interior dos vários movimentos de resistência, do passado e do presente. Ao ignorar a exclusão estrutural de determinados grupos ${ }^{13}$ não fazemos mais que criar e exibir as fragilidades que não cessam de ser cooptadas pelo inimigo. E, por isso mesmo, é a mulher quem fraqueja. Não por ser a suscetibilidade uma característica, por assim dizer, intrínseca ao feminino; mas porque o contínuo silenciamento que lhe fora imposto oportunizou a abertura do espaço onde a vulnerabilidade se alojou. Não é, portanto, a mulher quem está, naturalmente, mais vulnerável ao erro; é a racionalidade masculina e hegemônica que nos torna cada vez mais suscetíveis que nos impele a acolher as mais perversas formas de legitimação porque, expostas constantemente aos mais variados tipos de opressão, tal como a narradora, não nos sentimos autorizadas a ignorar as parcas chances de converter nosso silenciamento em grito.
13. Referimo-nos às pessoas em condição de extrema pobreza; às mulheres; aos indígenas; aos negros e negras; à população LGBTQI+, para citar apenas algun grupos continuamente excluídos do todo social. 
Longe de legitimar o consumo alienado como um meio de libertação, o romance confronta o absurdo pressuposto no qual fundamenta-se a lógica falocêntrica tecendo uma dupla crítica: de um lado, desnaturaliza a suposição misógina que o sustenta ao perscrutar de onde vem essa fragilidade "intrinsecamente" feminina; de outro, sugere ser o contínuo fracasso desse nosso presente - simbolizado, aqui, pelo desejo de consumo irrefreável - uma espécie de consequência dessa hegemônica racionalidade castradora, débil e negligente.

Assim, sem perder de vista a imagem do inimigo mais evidente, Jamais o fogo nunca não se exime de interpelar, ta mbém, o modus operandi daqueles que se colocava $\mathrm{m}$ - e ainda se colocam - do lado oposto. A essa reflexão feminina, que se presta a compreender o que já foi e o que ainda é, certas perguntas são inescapáveis. Qual é a medida da distância - porque, sim, há uma distância e isso não pode jamais ser ignorado - que separa a opressão do regime ditatorial e aquela da militância? Como podem polos tão antagônicos cruzarem-se em determinados pontos? O que se esconde por detrás dessa nossa derrota que parece estar, ainda, em curso? Daí a importância da revisão crítica. Daí a relevância da rememoração. Daí a necessidade de resgatar e expor opressões submersas que, não apenas não se prendem a determinados grupos ou espectros políticos, como também atravessam, incansavelmente, o tempo histórico.

Nesse sentido, o que essa passagem enigmática parece, sub-repticiamente, sugerir é a ineficácia do gesto repetitivo de direcionar a crítica apenas aos inimigos mais escandalosa mente visíveis. $O$ que esta passagem enigmática parece sugerir é que um combate à opressão que não se perfaz pelo questionamento de certos critérios de valoração está, de antemão, fadado ao fracasso. Em última instância, o que a revisão desse episódio incômodo, irônico e a mbíguo traz à baila é a debilidade de um programa político falocêntrico que, porque exagerada mente "lógico", não apenas tornou-se incapaz de vislumbrar, como também, em certo sentido, facilitou a construção da armadilha na qual, cedo ou tarde, cairia.

Mas, se no passado, a mulher acolhera sem qualquer ressalva as orientações recitando "sem duvidar, sem pausa, sem o menor titubeio" (ELTIT, 2017, p. 114) as diretrizes teóricas que a orientavam e ocupou de modo resignado cada uma das posições que lhe foram impostas, no presente da rememoração o erro não se repete. Seu trabalho de memória - ao voltar-se para materialidade do corpo e para potência dos afetos - aponta, justamente, para uma inversão. A legitimidade de uma razão 
feminina, é o que reivindica essa mulher. A edificação de uma forma de resistência que não ignore a dimensão sensível; que se negue a medir a consistência de seus procedimentos pela métrica masculina. Uma forma de resistência que se fundamente num outro tipo de racionalidade: por meio de uma rejeição enfática da razão instrumental, essa mulher expõe a potência crítica suas reminiscências sensoriais.

Ao propor uma outra formatação àquilo que chamamos de inteligibilidade, Jamais o fogo nunca apresenta-nos a possibilidade de compreender o exercício do pensamento de um outro modo, mais dissensual, político, corpóreo, sensível e, sobretudo, contra-hegemônico. Um tipo de compreensão que somente o olhar de um ser-mulher é capaz abrigar. Muito além de dar voz a um corpo marginalizado, mais que instituir-se como espaço de fala a quem experimenta o próprio apagamento, perscrutar o passado desde um ponto de vista feminino é inserir na discussão questões, continua mente, desprezadas. Isso porque, se por um lado, é preciso reconhecer o fato de a brava resistência ser um dos contornos mais marcantes da militância; por outro, é forçoso não negligenciar que sua estrutura machista - e, portanto, controversa - é, do mesmo modo, um forte demarcador de sua configuração. Nas narrativas que se debruçam sobre o tema da ditadura, contudo, esse traço é posto de lado com certa frequência. De fato, a relação entre o Estado e a militância compõe-se pelo confronto de duas forças absolutamente desproporcionais o que, de certo modo, explica essa hesitação. É tênue a linha que separa uma crítica responsável à estrutura militante da condescendência com o assédio institucional e, assim sendo, o risco em se criar uma relação de falsa semelhança é sempre iminente. Mas, ser mulher é, antes de mais nada, expor-se ao risco. E, assim sendo, uma feminina releitura histórica não pode se abster de cometer certas impertinências. Perscrutar a ditadura militar escrutinando a falocêntrica militância é dispor-se a remexer naquilo que, nas ruínas do passado, está mais submerso. O protagonismo desse corpo feminino é, portanto, o que possibilita ao romance elaborar um movimento duplo: de um lado, constitui-se como espaço de fala para a voz mais severamente silenciada, de outro, se dispõe a investigar as diversas dimensões que constituem esse silenciamento.

Para interpelar a histórica opressão de gênero, Eltit, não por acaso, questiona a falocêntrica lógica hegemônica unindo pensamento e corpo; edificando um corpo-pensamento que põe em ato uma outra forma de racionalidade. A inteligibilidade corporal na qual se fundamenta o relato que guia Jamais o fogo nunca, ao interrogar o 
que já foi e o que ainda é submetendo-se tão somente à legislação oblíqua da memória, opõe-se à racionalidade linear e totalizante cuja pretensão de verdade encerra o sentido dos acontecimentos. Por meio da construção dessa racionalidade sensivelmente dialética, que se sabe ambígua, inconstante e potente; que recusa o distanciamento e desconfia da objetividade; que se ocupa tanto menos dos fatos quanto mais dos afetos, Eltit apresenta-nos um tipo de aproximação à História que ecoa, uma vez mais, a voz de Walter Benja min. "Articular o passado historicamente", ele escreve, "não significa conhecê-lo 'tal como ele propriamente foi'. Significa apoderar-se de uma lembrança tal como ela lampeja num instante de perigo" (BENJAMIN apud LÖWY, 2005, p. 65). Prescindindo de fazer concessões artísticas em nome de um objetivo extraliterário, antes de "espelhar" a realidade, o romance acrescenta a ela aquilo que the foi suprimido. Explorando ao máximo a potência discursiva da letra, evidenciando o completo desinteresse da fabulação pelo imperativo positivista, Eltit elabora uma aproximação ao passado que traz à luz questões incontornáveis - sobretudo a esse nosso colapsado presente - e, de um modo literariamente político, edifica reflexões que se postam como vigorosas linhas de fuga.

A ficção, embora violentamente distante de um "decodificar” da realidade, ou precisamente por isso, é capaz de nos colocar diante daquilo que somos e apontar para o que poderíamos ser. "Mas este é um dia de um século diferente, de uma época carente de marcas, um século [...] que no entanto, somos obrigados a experimentar" (ELTIT, 2017, p. 25-26). Incitando um exercício crítico ante a História - ainda absoluta mente necessário -, apresentando-nos a potência de uma racionalidade sensível e feminina, Jamais o fogo nunca posta-se como uma narrativa aberta ao por vir porque permite a um corpo-ruína, marginalizado e suspenso no tempo, falar. Saberemos nós, no entanto, ouvir?

\section{REFERÊNCIAS}

BENJAMIN, Walter. Sobre o conceito da história. In.

Magia e técnica, arte e política: ensaios sobre literatura e história da cultura. Tradução de Sérgio Paulo Rouanet, 8. ed. São Paulo: Brasiliense, 2012 (Obras Escolhidas, 1).

ELTIT, Diamela. Jamais o fogo nunca. Trad. Julian Fuks. Belo Horizonte: Relicário Edições, 2017.

Jamás el fuego nunca. Santiago de Chile: Editorial Planeta Chilena S.A., 2007.

GAGNEBIN, Jeanne Marie. Walter Benjamin: os cacos da história. São Paulo: n-1 edições, 2018. 
KLEIN, Naomi. A doutrina do choque: a ascensão do capitalismo de desastre. Rio de Janeiro: Nova Fronteira 2008

KONDER, Leandro. Walter Benjamin: o marxismo da melancolia. Rio de Janeiro: Civilização Brasileira, 1999

LÖWY, Michel. Walter Benjamin: aviso de incêndio: uma leitura das teses "Sobre o conceito de história". Trad. Wanda

Nogueira Caldeira Brant, [tradução das teses] Jeanne Marie Gagnebin, Marcos Lutz Müller. São Paulo: Boitempo, 2005.

OLIVEIRA-WILLIAMS, Maria Rosa. La década de 70 em e cono sur. Romance Quarterly, 2010, vol. 57, p. 43-62.

Recebido em: 09-04-2020 Aceito em: 19-03-2021. 